\title{
FROM PROTOTYPICAL TO PROTOTYPING: MASS- CUSTOMIZATION VERSUS 2OTH CENTURY UTOPIAS IN ARCHITECTURE AND URBAN DESIGN
}

\section{DO PROTÓTIPO AO PROTOTIPADO: PERSONALIZAÇÃO EM MASSA VERSUS UTOPIAS DO SÉCULO XX NA ARQUITETURA E URBANISMO}

\author{
Gabriela Celani ${ }^{1}$ \\ Universidade Estadual de Campinas, Campinas, SP, Brasil, celani@fec.unicamp.br \\ Rafael Urano de Carvalho Frajndlich ${ }^{2}$ \\ Universidade Estadual de Campinas, Campinas, SP, Brasil, urano@fec.unicamp.br
}

\section{Resumo}

Este trabalho procura estabelecer conexões entre as quatro fases da Revolução Industrial e utopias propostas nas áreas de arquitetura e desenho urbano. $\mathrm{O}$ artigo começa com uma revisão geral das quatro fases da industrialização, tentando estabelecer conexões com as respectivas tendências arquitetônicas e urbanas em cada etapa. Da mesma maneira que a Segunda Revolução Industrial e seu novo sistema de produção em massa influenciaram as utopias modernas no início do século XX, os métodos da Terceira e Quarta Revoluções Industriais têm impulsionado novas utopias contemporâneas. A fim de ilustrar essa tese, são apresentados exemplos em diferentes escalas: produtos de consumo, componentes construtivos, unidades habitacionais e desenho urbano. Foi possível concluir que a principal diferença entre as utopias modernas e contemporâneas é uma mudança da maneira de pensar "top-down" para processos "bottom-up" nas diferentes escalas. Novos sistemas de CAD paramétrico e novas máquinas de produção pessoal, tais como as fresadoras $\mathrm{CNC}$, cortadoras a laser e impressoras 3D, e o conceito de personalização em massa, estão permitindo que os usuários se tornem mais participantes na produção de seus bens de consumo, residências, e até mesmo os espaços urbanos. O trabalho termina perguntando aos arquitetos e urbanistas quais serão as próximas utopias, com base nas novas tecnologias esperadas para as próximas décadas.

Palavras-chave: Utopias modernas. Revolução industrial. Produção flexível. Mass-customization. FabCity.

\begin{abstract}
This paper seeks to establish connections between the four phases of the Industrial Revolution and architectural utopias in architecture and urban design. We start with an overview of the four phases of industrialization, trying to establish connections to the respective architectural and urban trends at each phase. We argue that in the same way the Second Industrial Revolution and its new mass production system influenced some Modern utopias at the beginning of the 20th century, the Third and Fourth Industrial Revolution methods have boosted new contemporary utopias. In order to illustrate this thesis, we looked at examples in different scales: consumer products, building components, housing units and urban design. We concluded that the main difference between modern and contemporary utopias is a shift from top-down to bottom-up processes across the different scales. New parametric CAD software and personal production machines, such as CNC-routers, laser cutters and 3D-printers, and the concept of masscustomization, are making it possible for users to be more participant in the production of their own products, homes, and even the urban spaces. The paper ends with an inquiry about which will be the next utopias, based on the technologies expected to reach tipping points in the next decades.
\end{abstract}

Keywords: Modern utopias, industrial revolution, flexible production, mass-customization, FabCity.

How to cite this article:

CELANI, Gabriela; FRAJNDLICH, Rafael Urano de Carvalho. From prototypical to prototyping: mass-customization versus 20th century utopias in architecture and urban design. PARC Research in Architecture and Building Construction, [S.I.], v. 7, n. 3, p. 160-169, oct. 2016. ISSN 19806809. Available at: <http://periodicos.sbu.unicamp.br/ojs/index.php/parc/article/view/8647348>. Date accessed: 15 mar. 2017. doi:http://dx.doi.org/10.20396/parc.v7i3.8647348. 


\section{Introduction}

Most Modern utopias relied on the new possibilities of industrial progress. Some of them imagined a city with an aesthetical approach to the standards of the machine, hoping to pre-produce all of its components and then spread them throughout the country, creating efficient, fully functionalized urban structures (LE CORBUSIER, 1987; PILGRIM; TASHJIAN; WILSON, 1986). Likewise, at the break of the 21 st century, many new trends try to reach new perspectives of architecture and urban design through the appropriation of digital technologies and the fundamental changes seen in the production system (KOLAREVIC, 2003).

If 21 st and 20th century utopias share a common ground in the belief that the virtualities of new technological trends act as an aesthetic challenge to redesign production and therefore the cities.

However, in each century the approach is different, especially with regards to the "proper" way of transposing concepts from industry to architecture and urban design. Pre-World War II and immediate post-World War I architects worked with the notion that an industrial archetype was necessary to conciliate art and industry, rendering a prototypical approach to construction where one very well designed object would fit society as a whole. Walter Gropius, founder of Bauhaus, synthetized such intent in one internal memorandum: "One can expect that the work in Bauhaus workshops gradually drives towards the creation of unique typical objects" (GROPIUS, 1980, p.70).

All the urban avant-garde proposals derived from this notion of industrial design, which relied on an interpretation of art and life based on a prototypical scope. ${ }^{1}$ By the end of the 20th century, however, prototypical design was heavily criticized, in a process that had been initiated in the fifties with Team $\mathrm{X}$ and in the sixties as part of post-modern overall critiques to the avant-gardes, having gained momentum during the nineties with exhibitions like Non-Standard Architecture (2003) and the new production systems that allowed mass-customization to take command over standard-like form conception, following the growth of individualized, plural uses of the city.

Initiatives like the Smart cities or the Fabcity initiative appeared as part of these new manifestations. On defending a city design based on shared design and spread out fablabs where anything can be produced according to specific necessities of local inhabitants, the Fabcity takes a stand on the possibilities of widely comprehensive urbanism postulations in a post-prototypical world. However, far from being the complete antithesis of the modern world, it inherits the ambitions of the modernist utopias to design the whole productive levels in the contemporary cities. If 'prototype' refers to an universally pertinent object that industry spreads for all, 'prototyping' subverts this paradigm turning it into a stance to approach urban conception, where users participate not with contingent improvements, but with the industrial design, serialization and customization of the city.

This paper discusses how modern and contemporary architecture and urban design show simultaneously similar and different, approaches to a teleological design of buildings and cities - as technological utopias in which not only the form conception is at stake, but also its production systems and the collective and individual profiles of its inhabitants. We will expose the appeals of industrial architecture as part of a utopian urbanism and will establish a parallel with contemporary concepts of shared design, local approaches to global structures and how it points out to new possibilities of architectural experiences interested in an open minded appropriation of digital technologies to rethink how humans should live and produce together.

\section{Four Industrial Revolutions}

Figure 1 shows the major milestones in industrial technology developments since the invention of the mechanical loom, in 1784, and their corresponding influences in architecture and urban design. The Industrial Revolution's phases are categorized according to the new technologies that have been introduced and that have modified the way things are produced. Each of the four phases had important impacts in architecture and urban design utopias, usually with a slight delay in comparison to industrial developments.

\section{First Industrial Revolution}

The First Industrial Revolution, in the 19th century, was characterized by the use of water and steam power and by the railroad. In engineering, industrially-produced cast iron parts became a common construction material, allowing larger spans, but still trying to mimic traditional forms. This new production paradigm structurally changed centuries old Europeans Capitals like Paris and London (TÖNNIES, 2002). A new set of necessities appears as urban design became more concerned with transportation infrastructure, both for people and for goods, which included trains, trams and cable cars. Haussmann's (18531871) and Cerda's (1860) plans are examples of the application of mid 19th century urban utopias. 
Figure 1 - The four stages of the Industrial Revolution and the respective architectural utopias

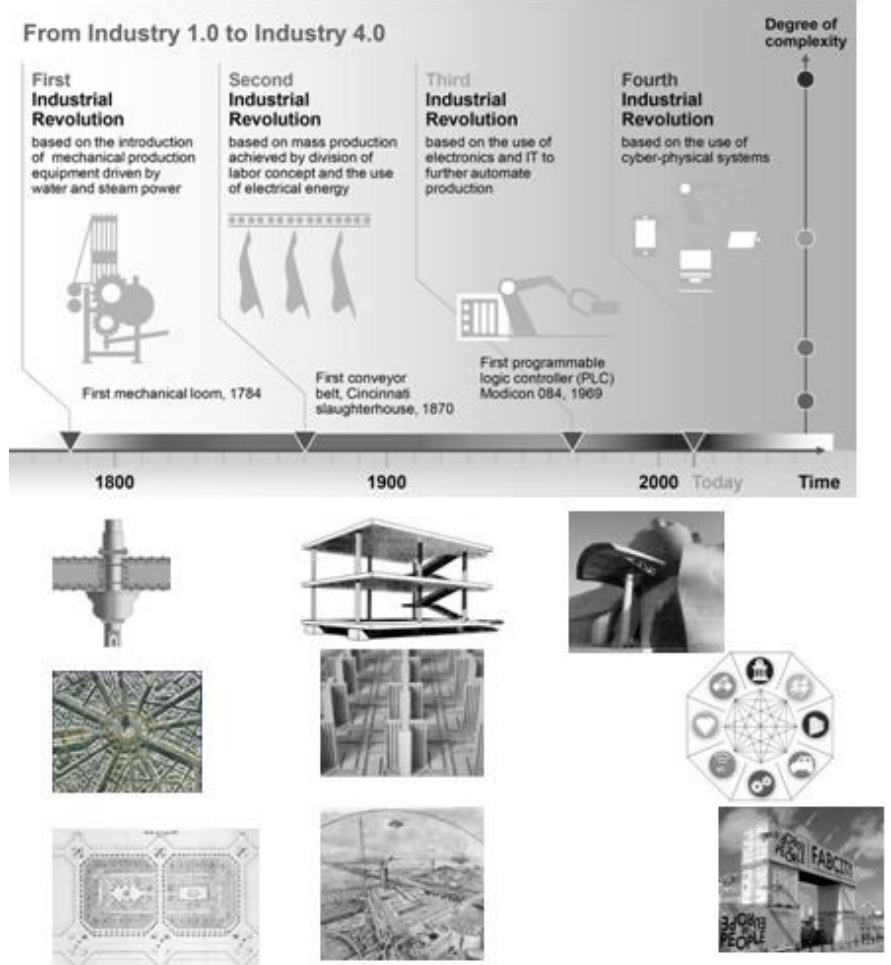

Source: Adapted from http://www.well-comm.es/wellcommunity/que-es-la-industria-4-0/.

\section{Second Industrial Revolution}

In the Second Industrial Revolution, in the turn of the century and first decades of the 20th, the use of electrical energy and the division of labor led to the new concepts of mass-production and economy of scale. A generation of artists gave a new approach to art as a dialogue with the new perception trend imposed by the life in the metropolis (SIMMEL, 1969; BENJAMIN, 2006; TAFURI, 1977). Along with these were the avant-gardes, architecture responded in a wide approach seeking to integrate mass produced component design with urban utopias, leading to the concept of mass-produced houses, seeking an industrial aesthetics. The most significant examples of this thinking are probably Le Corbusier's maison dom-ino experiences in (1914) and Ernst May prefab experiences in Neue bauen's Frankfurt (1925-1930).

The mass-produced house, which was conceived as an utopia, became a common reality after World War II, when pre-cast concrete construction elements became commonplace in the reconstruction of Europe. In the urban utopias of the first decades of the 20th century, cities were conceived for the new mass-produced cars, both as a continuous urban tissue, as in Le Corbusier's Ville Radieuse, of 1924, or as infinite sprawls in Frank Lloyd Wright's Broadacre City, of 1932.

\section{Third Industrial Revolution}

In the 1970s, new computer-controlled, programmable machines started to change again the logics of industrial production, resulting in a Third Industrial Revolution. The main characteristic of these machines was flexibility, which means that they had the ability to create different product types, or run the same procedures with different parameters, allowing the mass production of individuallydesigned parts. A good example of flexible manufacturing machine is the laser cutter. Instead of investing in a specific knife for cutting out a specific shape, factories are now investing in machines that can cut any shape specified in a digital file. This concept is called file-to-factory, and it also applies to 3D-printing and CNC direct carving, which can substitute molds. There are also new developments in flexible, CNC-controlled pin-molds, for example for the production of double-curved glass panels.

Architects since then largely explored the concept of mass customization, first identified by Stan Davis in his book Future Perfect (1987), as a new utopia that could completely eradicate repetition and boredom from buildings, especially in the case of housing.

Frank Gehry's Guggenheim Museum in Bilbao, built in 1997, is acknowledged by the literature as the first largescale building to effectively employ this technology. In this building, thousands of sections of its titanium façade were individually curved with a computer-controlled calender, which made the work feasible, at least time wise. Nowadays many buildings use this technology and new rationalization methods have been developed to make this technology feasible also resource wise.

\section{Fourth Industrial Revolution}

According to Schwab (2016), the Forth Industrial Revolution is

building on the third, the digital revolution that has been occurring since the middle of the last century. It is characterized by a fusion of technologies that is blurring the lines between the physical, digital, and biological spheres.

The Fourth Industrial Revolution's milestone, just a few decades after the previous phase, is the cyber-physical system (CPS), a mechanism controlled by computer-based algorithms and integrated with the Internet, which depends on processing power, storage capacity, cloud computing, access to big data and big analytics (making sense of big data). Parts being produced in an industrial plant now "know" where they are and they can even "look for" other parts that match them, thus improving the efficiency and sustainability of the process. This technology is also known as Internet of Things (IOT), or as Internet of Everything (IOE), and the plants that use it are called "smart factories". 
Schwab (2016) states that one of the main characteristics of this phase is that its impacts are no longer limited to industrial applications:

\begin{abstract}
...the breadth and depth of these changes herald the transformation of entire systems of production, management, and governance. The possibilities of billions of people connected by mobile devices, with unprecedented processing power, storage capacity, and access to knowledge, are unlimited. And these possibilities will be multiplied by emerging technology breakthroughs in fields such as artificial intelligence, robotics, the Internet of Things, autonomous vehicles, 3-D printing, nanotechnology, biotechnology, materials science, energy storage, and quantum computing.
\end{abstract}

The concept of Smart Cities, which also appeared in the first decade of the 21 st century, is directly related to this technology. Smart Cities are defined by Townsend (2013) as "places where information technology is combined with infra-structure, architecture, everyday objects, and even our bodies, to address social, economic, and environmental problems".

The Smart City is a new urban utopia with two variants: the top-down and the bottom-up movements. In the first case, it is the result of big investments and a powerful marketing plan created by large companies such as IBM, Cisco and Siemens to sell state-of-the-art technologies to city administration offices. These companies provide turnkey solutions that are worth millions of dollars for dealing with issues such as urban crime (e.g. IBM's Operations Center of the City of Rio - Singer, 2012) or energy management (e.g. Cisco's smart grid systems ${ }^{2}$ ) .

A bottom-up variant of Smart Cities, far more utopical, is the FabCity initiative, which uses technologies initially developed in the Third Industrial Revolution, in particular computer-controlled machines, such as 3D-printers, associated with internet networks. This concept came up in 2011 during Fab7, the seventh FabLab world conference. By pledging to become a FabCity, a city agrees to follow a road map that includes creating FabLabs, makers spaces, community gardens, recycling stations and self-sustaining houses in terms of production energy and water reuse. In the maker spaces citizens may produce their own consumer goods or develop new products that can be replicated in other locations. Thus, the city starts to import and export digitally-transmitted data instead of physical goods, decreasing transportation of products into the city and of garbage out of it. Unlike the concept of Smart City, FabCity counts more on people's initiatives than in large investments. This utopia is associated with education for innovation and the training of a new generation of environmentally conscious individuals, less consumptive and more creative.

\section{From top-down to bottom-up, across the different scales}

Most of the twentieth century utopias had a clear topdown approach, no matter how much it favored a freedom of the individuals in a life among green areas and efficient housing and transporting systems (such as in Wright's Broadacre City).

On a historical analysis, avant-garde trends actually picked a decision-making side on oppositional positions. 19th century urban design was typically top-down (such as in Patté, Howard, Hénard, Haussmannand others), but its utopical approach included some bottom-up initiatives like Fourier's Falansterium, Owen's New Savannah or even Morus formless Utopia (RYKWERT, 2000). Corbusier, Hilberseimer, Ginzburg and other architects from the early 20 th century were more interested in the pragmatic aspects of the 1800s urban design spectrum, which may explain why top-down was the direction of choice for these pioneers.

However, the notion of personal adjustments or what would be later called mass-customization wasn't completely strange in their conception. The Maison Domino itself already had some customization features, but these possibilities diminished severely as Corbusier raised the scale of his designs. The Ville pour trois million d'habitants was completely top-down oriented, possibly not because of an authoritarian understanding of the modern city, but because Corbusier believed in the symmetry between industry and society (Figure 2).

\begin{abstract}
"Throughout the world we see the array of mighty powers, both in the industrial and in the social spheres; we see, emerging from the chaos, ordered and logical aspirations" (LE CORBUSIER, 1987, p.39).
\end{abstract}

Figure 2 - Building Sketch presented by Le Corbusier: serialized construction of the city of tomorrow

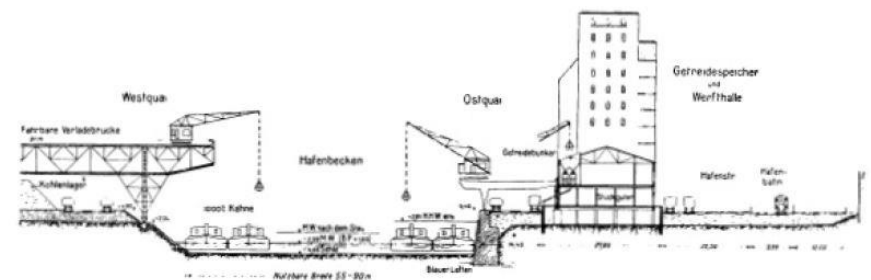

Source: Le Corbusier, The city of tomorrow and its planning, New York: Dover, 1987

As such logical aspiration applies to every machine and human being likewise, the architect is the figure that gives form to such naturally given harmony ${ }^{3}$.

Prewar industrial driven architecture in Europe roughly embraced this interpretation of the prototypical object as a missing link between men and machine. The prototype 
gathers and filters the universal aspect of our everyday tools and allows them to be widespread.

Postwar architects did not drift away from this paradigm, but the impetus towards mass-customization became rather prominent. In the forties, Jean Prouvé recalled Corbusier's claim for industrial architecture showing how technology had already revolutionized mass transports and aviation business (Figure 3).

"A building is just another object that needs to be constructed. Why not treat it therefore as an item entirely designed, manufactured and marketed by large industries which require to be set up?" (PROUVÉ, 1971, p.24).

Figure 3 - Jean Prouvé designs prototypical houses for Abbé Pierre
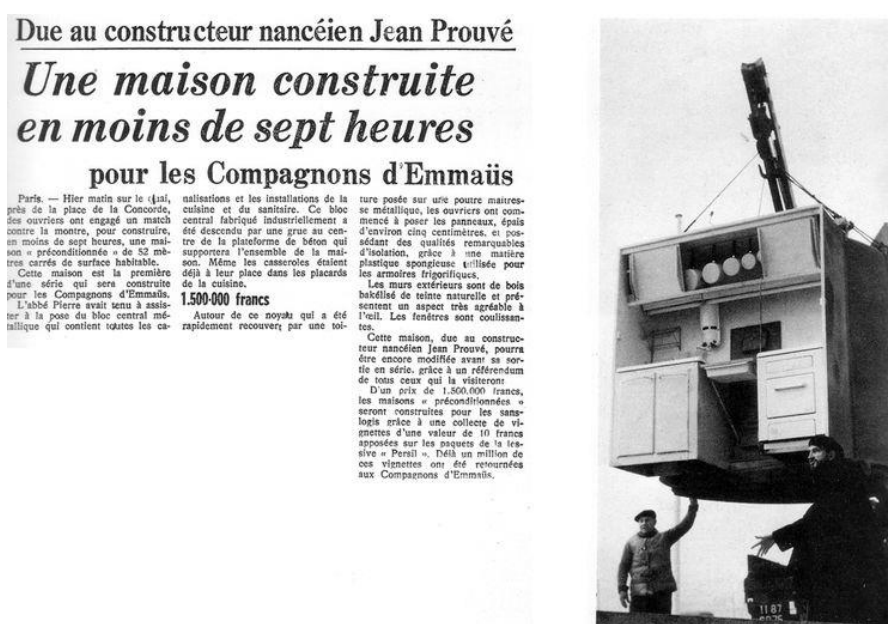

Source: Prouvé, Jean, Jean Prouvé. Une architecture par l'industrie. Zurich: Les Editions d'Architecture Artemis, 1971.

However, when the component design becomes an issue, Prouvé strives for flexibility. In his design of House of Madame Seynave, the plan is determined by the connection of square-shaped reinforced concrete pieces that may be rendered together in many dispositions. The house becomes not a model, but the application of a prototypical design on the scale of the component.

From a strictly technologic point of view, that was not a novelty: Russian constructivists and German Neue Bauen did similar experiences during Prewar. The overall approach to the individual is what changed the game: one could consider personal customization in harmony with prototypical architecture ${ }^{4}$.

Going down the chain of scales, component design is the first that leans towards new possibilities of masscustomization. Prewar avant-gardes had already paved the road through which small scale reaches large scale, so postwar architects quickly became inspired by the possibilities of mending pieces together in order to design the whole city.
Postwar urban utopias used these new mass-customization trends with prototypical design intensively. From Archigram's Plug-in city to Yona Friedman's Mobile Architecture (Figure 4), the main idea was to establish an overall structure where customized parts could fit in. While Archigram had a more pop-art critical approach, Friedman, on the other hand, believed in the virtualities of a third industrial revolution where "the future user will be able to plan for himself and with other people" (FRIEDMAN, 1975, p. IX).

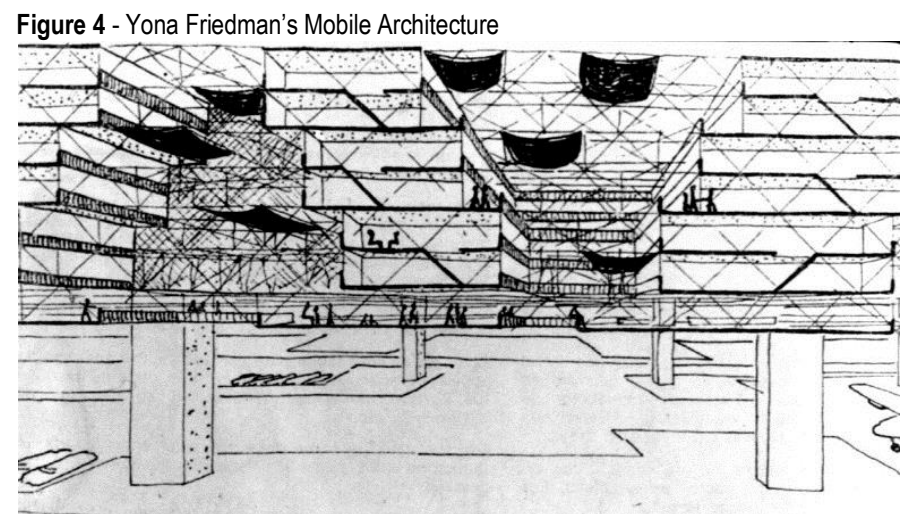

Source: Friedman, Yona. Une utopie réalisée. Paris: Musée d'Art Moderne de la Ville de Paris, 1975.

Friedman's proposal points towards a subversion from top-down to bottom-up. All of his spatial structures are a background, necessary drawback in order to sustain industrial component parts with a flexibility spectrum that allows encompassing most individual requirements. Even the spatial structure itself is subject to a degree of customization. In the Flatwriter (1970), considered a "simple tool for the self planner" a special typewriter could manage individual desires related to space and design "the actual plan of the apartment he wished for himself”' (FRIEDMAN, 1975, p. 68).

On the verge of computer aided design, Friedman sensed the growing necessity of customization run parallel to the raise of data management possibilities applied to industrial series. The following decades that allowed Zaha Hadid's optimization of parts in Galaxy Soho or the nowadays widely celebrated 3D-printed house all remount to this process in which technology and social leaps were a critical challenge to the prototypical design approach.

Eventually, the prototypical had to adapt by radically turning into prototyping: from top-down to bottom-up oriented, blurring the borders between users and creators. Such blur is an already exhaustive common sense applied to our era. Our hypothesis, however, tries to shed new light to it in the scale of urban design, a scale that remained relatively immune to such trends, although it has felt deeply the vicissitudes of architecture making as it spread through all other scales. 


\section{The building component}

Friedman's interests largely implied mass-customization. However, the industry in the seventies still had its standardized limits and expected - and required - a prototypical way of thinking. By then, modernist legacy already had established guidelines to whoever wanted to connect industry to art. It became a widely renowned common place.

Industry, on the other hand, had other frontiers to cross. As the building component industry remained under these strict conditions, production changed as the third industrial revolution set new standards for mass-production, no longer tying it to the needs of archetypical objects and parts. The prototype was becoming obsolete as a way of thinking, as mass-customization became an established term in most goods and service companies:

These firms have thrown away the old paradigm of Mass Production whose focus was efficiency through stability and control. Through the application of technology and new management methods, they have found their way to a new paradigm by creating variety and customization through flexibility and quick responsiveness. This is the controlling focus of the new paradigm, Mass Customization (PINE, 1999, p.44).

Pine (1999) words above synthesizes the overall management shift happening in the late eighties and early nineties. Such shift would perfectly fit in the breakthrough of the internet and its fully customized environment, and would set the paradigm for a new innovative, on-demand customer-oriented industry.

How has architecture fit into those trends? Frank Gehry's Guggenheim Bilbao is an useful example of a transition stage where suppliers-supported innovation allowed unforeseen freedom of creation and form-making by relying on mass-customized production methods. The aforementioned development of a tailor-made software technology to render the shape designed by the architectural practice in one end and the optimized cladding pieces on the other reveal that the component now is free from prototypical limitations. Experiences like Zaha Hadid's Galaxy Soho equally point towards this new association of component design and algorithmic optimization. Zaha's curved façades pass through the scrutiny of a software that conciliates its free-form cladding with a flexible mass-customized steel shaping industrial process. As usual, since the first avant-gardes, these component-mass-shaping trends quickly trespass scales, and mass-customization in architecture may reach urban utopias inspirations.

\section{The housing unit}

Housing units have been a laboratory for architectural industrialization. Both Prewar and Postwar prototypical experiences relied on house-making in order to verify theories and postulations. Avant-garde urban design set a standard of always having house units as the starting points of their proposals. From Siedlungen, Höffe and other experiences, urban utopias have found a practical output on mass housing.

If during the Prewar mass housing had its golden age, its Postwar experiences are commonly though as the Achilles heel of modernist utopias. From East Berlin to Saint Louis' Pruitt Igoe, top-down CIAM-inspired neighborhoods fell prey to accusations of authoritarian design, old fashioned Behaviorist architecture that ultimately gave modernist urban design a bad reputation (JENCKS, 1972).

As a result, contemporary housing projects usually explore the participatory process involving future users, as a way to avoid accusations of top-down arbitrariness. During the same seventies when Friedman developed its Mobile utopia, architects were moving away from high technology-enabled mass housing and were focusing on contextual approaches in order to establish a common ground between users and architects. Technological trends only entered this scale under the umbrella of masscustomization possibilities. Being able to give industrial widespread in a customized environment motivates several new initiatives in the beginning of the 21 st century.

Lacaton \& Vassal and Druot's intervention on the Grand ensembles in the outskirts of Paris show a will to give identity to these areas, while keeping its overall infrastructure, in a Friedman-inspired customization of parts. These initiatives remain top-down schemes, although some younger practices try to work with masshousing legacy on a bottom-up system. The Hacking Gomorra project (Figure 5), by CODesign Lab, intervenes in a typical modernist mass-housing project Velle di Scampia in Naples by giving its inhabitants the power to redesign their own façades and 3D-print them in concrete. The custom-made parts are then raised by cranes and attached to the building from the outside. The project has not been built but the technology is actually available, at least in experimental mode.

Other examples of this type of utopic bottom-up housing design is the Wiki-House (Figure 6) and the 3D-print Canal House (Figure 7). The former offers customizable designs that can be downloaded and CNC-cut. The later, still under development, promises customers to design their houses online and have them custom 3D-printed. The 3D-print Canal House was presented to President Obama by the Dutch Prime Minister and Amsterdam's Mayor in 
an official visit to the Netherlands, as "a unique project because it combines history and future" (www.3ders.org, 2014).

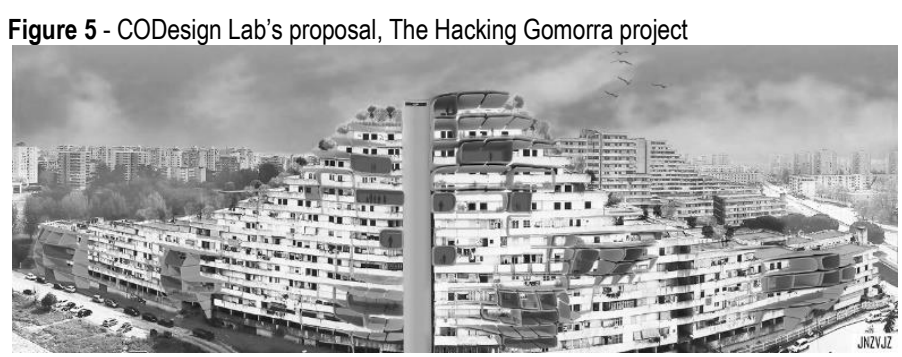

Source: CODesign Lab. Available at http://www.codesignlab.org/en/2014-02-09-22-4847/90-homepage/249-hacking-gomorra-productive-cities.html

Figure 6 - Wikihouse website

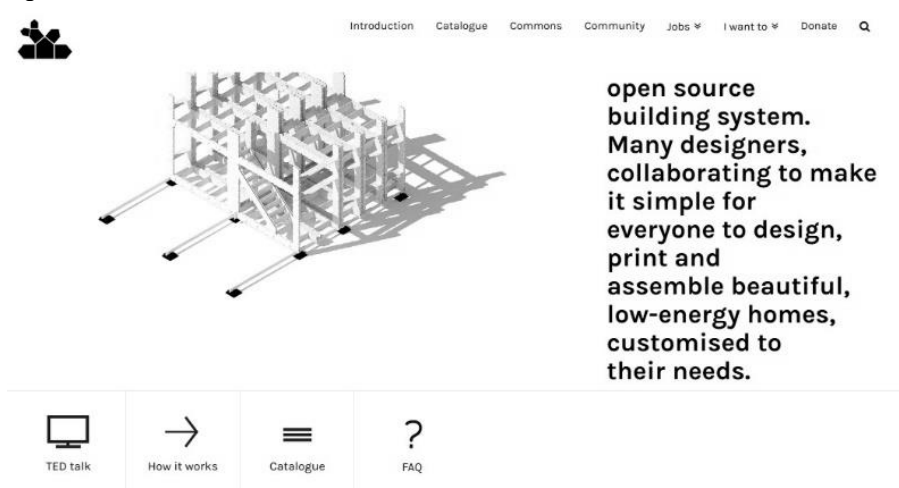

Source: http://www.wikihouse.cc/

Figure 7 - The 3D-print Canal House is presented to Obama during his visit to the Netherlands

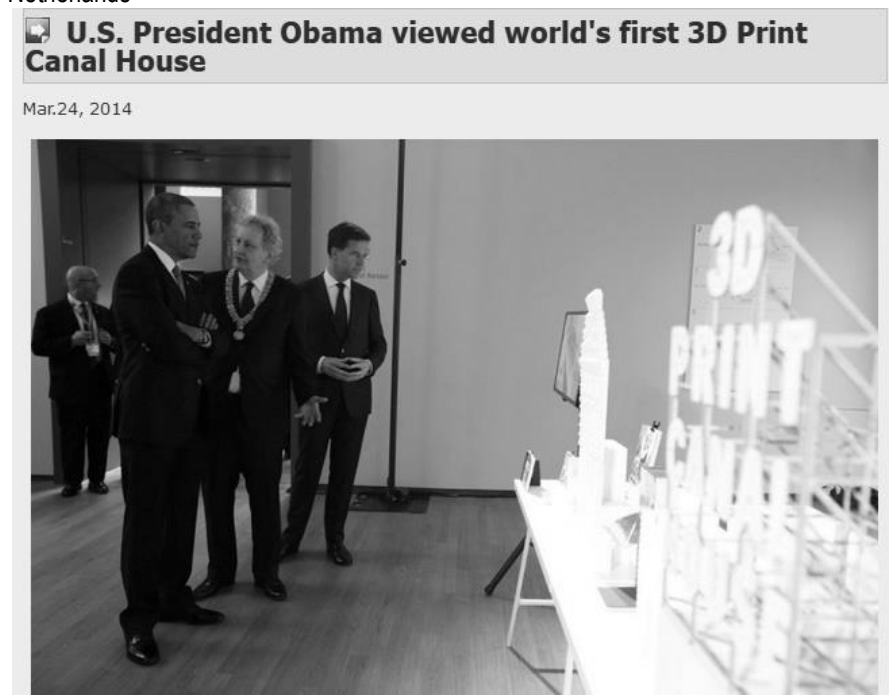

Source: http://www.3ders.org/articles/20140324-us-president-obama-viewed-3d-printcanal-house.html

Open source knowledge widespread by internet and 3Dprinted technologies pose a provocative turning point to the relationship between architecture and society.

The city

In the scale of the city, top-down methods, although milder than like on the Athens Charter, are still predominant, but new bottom-up initiatives start to appear and to prove themselves viable. Songdo, a Korean smart city set up as a huge shop-window to the world, is an example of the former. It is comparable to the modern urban utopias, but with a sustainability appeal (Figure 8). Behind this image, big high-tech companies such as Siemens, IBM and Cisco sell millionaire turn-in solutions for mayors who want to have total control over their cities' security, transport, traffic, energy grid and so on (TOWNSEND, 2013).

Figure 8 - Songdo, Korea: a contemporary top-down urban utopia

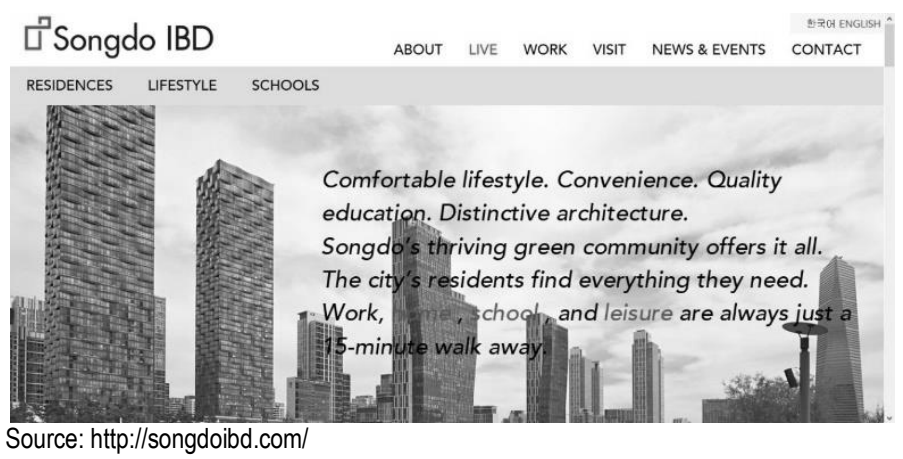

The Fabcity (Figure 9) initiative, on the other hand, adopts a bottom-up approach. It applies the core concept of the 4 th industrial revolution and proposes that every citizen becomes a producer of his/her own products, from vegetables to home appliances. The trend started in the early 2000s with the MIT Fablab network, which already has more than 500 digital fabrication labs throughout the world. Many metropolitan areas, like São Paulo, have also created their own Fablab - also called Maker Space networks, with similar purposes. The Fabcity builds on top of the maker movement, adding a new sustainability layer to it, just like the Smart city. Nine cities around the world have signed the Fabcity protocol so far, including Amsterdam, where the first Fabcity exhibition was held in 2016. The "roadmap" aims at of reducing the transportation of "bits" in and out of the city, and increasing the wireless transmission of bits (FABCITY, 2016).

\section{Conclusion}

Contemporary utopias rely on the new possibilities of industrial progress in a different sense than Modern utopias did. From a prototypical approach where design would be made by top architects to a prototyping there are similarities and differences which wind up in the top-down to bottom-up dichotomy. While the first recent architectural utopias appeared many decades after the industrial/technological advancements that inspired them, some of the contemporary utopias, such as Smart Cities, Fab Cities, the Wikihouse and the 3D-printed canal House, have been actually formulated along with or even before their driving technologies were fully adopted by the 


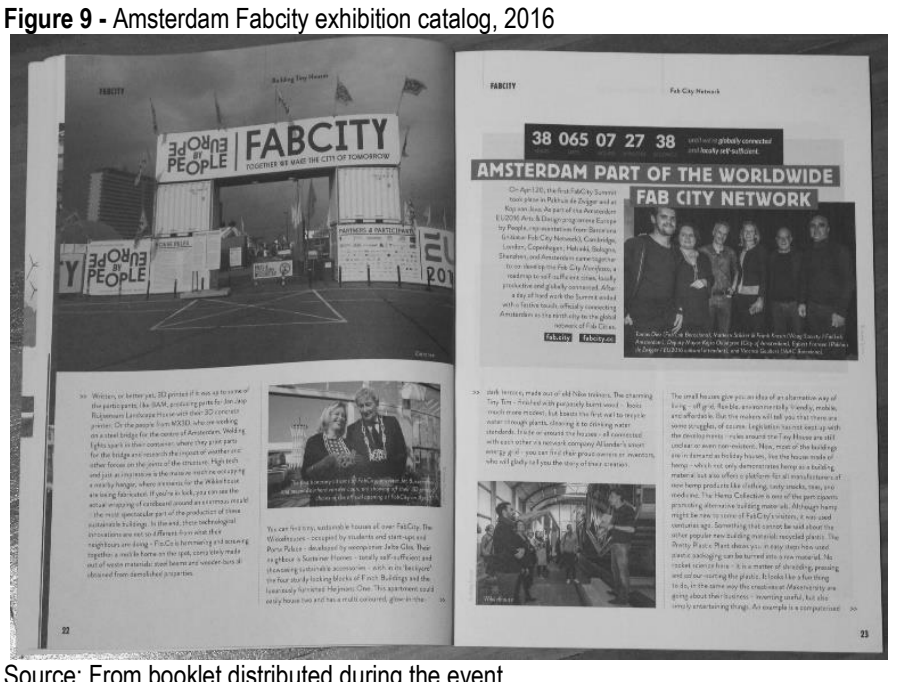

industry. New technologies are appearing at an ever-faster pace. In the late 1990s and early 2000s Bill Mitchell's trilogy about future cities - The City of Bits, E-topia and Me ++ The Cyborg Self and the Networked City previewed what we now call Smart Cities. Similarly, the Fab City initiative anticipates the Fourth Industrial Revolution, or perhaps even the Fifth, according to some authors $^{5}$, which is based on adaptability, resource efficiency, low-cost robots and distributed manufacturing, a technology that disintegrates the factory.

By looking at examples throughout the different scales, it was possible to notice that in general smaller scale utopias evolved from a bottom-up (with general-purpose components) to a top-down (with mass-customized parts) approach, while larger scale (city) utopias evolved from top-down master plans to bottom-up communities of makers. The new technologies being presently developed also point towards decentralization and entrepreneurship.

In the last World Economic Forum, held in Davos on September 2015, six technological developments were pointed out as the next "mega trends" (WORLD ECONOMIC FORUM, 2015):

1. People and the internet (how people connect with the world around them through new technologies, such as wearables and implants, interacting with objects and other people in new ways);

2. Computing, communications and storage everywhere (due to an exponential growth in the potential to access the internet, ubiquitous computing power and access to a supercomputers and unlimited storage capacity will be available everyone);

3. The Internet of Things (smaller, cheaper and smarter sensors will be present in homes, clothes, cities, transportation, energy networks and manufacturing processes.

4. Artificial intelligence (AI) and big data (exponential digitization of data about everything and everyone and the ability for software to learn, evolve, and handle new types of problems will make it possible to automate decisionmaking and jobs);

5. The sharing economy and distributed trust (new networks and platform-based social and economic models based on the internet, driving new business models and opportunities for social self-organization, with blockchain, the distributed database that is behind bitcoin transactions, replacing the need for third-party institutions to provide trust for financial, contract and voting activities);

6. The digitization of matter (3D-printing of physical objects from multiple materials, transforming industrial manufacturing and allowing distributed and even home production, with a range of applications that include the fabrication of equipment, food, prostheses and even organs, through bio-printing).

According to the same document, the widespread use of these new developments is no so far away. In a survey with experts based on a weighted average system, they have estimated that the use of 3D printing will become trivial by 2022 , most homes will be connected by 2024 , and the driverless car will be completely established in 2026, along with smart cities.

Which architectural and urban utopias will these innovations inspire in the next decades? Nowadays we see very initial influences, especially when compared with consolidated avant-garde contributions. However, it is already possible to foresee some challenges lingering on this shift from top-down to bottom-up decision making as the urge of technology widespread not only as a private service, but as part of a broad public initiative and the necessity to rethink our notion of education in urban design as a prominently peer to peer-oriented activity. It may sound farfetched, but so is the utopian thought.

\section{Acknowledgements}

The authors thank CNPq, FAPESP, CAPES and FAEPEX for constantly supporting their research. 


\section{Notes}

(1) The inhabitant of these utopias were equally optimized: experiences like Schlemmer's theatrical performances or even the late illations of Corbusier through the Modulor in the forties show that the modern utopias had strong expectations on designing a prototypical standardized and widespread human behavior, as part of the whole design of the city.

(2) See http://www.cisco.com/c/en/us/solutions/industries/energy/external-utilities-smart-grid.html

(3) For a better understanding on how Corbusier connected urban design, art and industry see Martins (1992).

(4) It is possible to argue that Le Corbusier's Plan Obus in Algiers considers customization of housing units décor, as his sketches show and how Tafuri pointed out in its "Architecture and Utopia". However, in that case, as Tafuri thoroughly shows, it sounds more like a 'blind spot' of industrial embracement than an actual customization through industrial design (TAFURI, 1977).

(5) Some authors actually are already associating this move to a Fifth Industrial Revolution. See, for example, Maxwell (2014).

\section{References}

BENJAMIN, Walter. Passagens. São Paulo and Belo Horizonte: Imprensa Oficial and UFMG, 2006.

LE CORBUSIER. The city of tomorrow and its planning, New York: Dover, 1987.

FABCITY. Locally productive, globally connected self-sufficient cities. Whitepaper. Access in: July, 31st, 2016. Available at: http://fab.city/whitepaper.pdf

FRIEDMAN, Yona. Une utopie réalisée. Paris: Musée d'Art Moderne de la Ville de Paris, 1975.

GROPIUS, Walter, "La vitalidad de la idea de la Bauhaus” In. WINGLER, Hans M.. La Bauhaus, Barcelona: GG, 1980, p. 68-71.

JENCKS, Charles. The language of post modern architecture. London: Academy Editions, 1977.

KOLAREVIC, Branko. Architecture in the Digital Age: Design and Manufacturing. London: Taylor \& Francis, 2003.

MARTINS, Carlos Alberto F.. Razón, ciudad y naturaleza. La génesis de los conceptos en el urbanismo de Le Corbusier. Madrid: ETSAM, 1992.

MAXWELL, Ian A. The fifth industrial revolution. Chemistry in Australia, Mar 2014, p.38. Access in: July, 31st, 2016. Available at: http://connection.ebscohost.com/c/articles/94768986/fifth-industrial-revolution

PILGRIM, Dianne H.; TASHJIAN, Dickram; WILSON, Richard Guy. The Machine Age in America 1918-1944. New York: Harry N. Abrams, Inc., 1986.

PINE, Joseph. Mass Customization. The new frontier in Business Competition. Boston: Harvard Business School Press, 1999.

PROUVÉ, Jean. Une architecture par l’industrie. Zurich: Les Editions d'Architecture Artemis, 1971.

RYKWERT, Joseph. The seduction of place: City in the Twenty-First Century. New York: Pantheon Books, 2000.

SCHWAB, Klaus. The Fourth Industrial Revolution: what it means, how to respond. World Economic Forum website, 14/Jan/2016. Access in: July, 31st, 2016. Available at: https://www.weforum.org/agenda/2016/01/the-fourth-industrial-revolutionwhat-it-means-and-how-to-respond/

SIMMEL, Georg. The Metropolis and the Mental Life. In. SENNET, Richard. Classic Essays on the Culture of the Cities. Englewood Cliffs: Prentice Hall, 1969, p. 47-60.

SINGER, Natasha. Mission Control, Built for Cities - I.B.M. Takes 'Smarter Cities' Concept to Rio de Janeiro. The New York Times, March 3, 2012. Access in: July, 31st, 2016. Available at: http://www.nytimes.com/2012/03/04/business/ibm-takes-smartercities-concept-to-rio-de-janeiro.html?_r=0

TAFURI, Manfredo. Progetto e utopia. Architettura e svillupo capitalistico. Bari: Laterza, 1977. 
CELANI, Grabriela; FRAJNDLICH, Rafael U. de C..

From prototypical to prototyping: mass-customization versus 20th century utopias in architecture and urban design

TÖNNIES, Ferdinand. Community and Society. Mineola: Dover, 2002.

TOWNSEND, Anthony M. Smart Cities - Big data, civic hackers, and the quest for a new utopia. New York: Norton, 2013.

WORLD ECONOMIC FORUM. Deep Shift Technology Tipping Points and Societal Impact. Global Agenda Council on the Future of Software \& Society. Survey Report - September 2015. Davos: World Economic Forum, 215, p.5. Access in: July, 31 st, 2016. Available at: http://www3.weforum.org/docs/WEF_GAC15_Technological_Tipping_Points_report_2015.pdf

WWW.3DERS.ORG. U.S. President Obama viewed world's first 3D Print Canal House. 24/mar/2014. Access in: July, 31st, 2016. Available at: http://www.3ders.org/articles/20140324-us-president-obama-viewed-3d-print-canal-house.html.

\section{${ }^{1}$ Gabriela Celani}

Arquiteta e urbanista. Professora Livre-Docente. FEC - UNICAMP. Rua Saturnino de Brito, 224, Cidade Universitária Zeferino Vaz, Campinas, SP, Brasil, 13083-889, CP 6143.

\section{${ }^{2}$ Rafael Urano de Carvalho Frajndlich}

Arquiteta e urbanista. Professor Doutor. FEC - UNICAMP. Rua Saturnino de Brito, 224, Cidade Universitária Zeferino Vaz, Campinas, SP, Brasil, 13083-889, CP 6143. 